\title{
Proposal international transport chain during the transport of tires
}

\author{
Lenka Černá $^{*}$, Vladislav Zitrický1, ${ }^{1}$ Peter Blaho ${ }^{2}$ and Peter Šulko ${ }^{3}$ \\ ${ }^{1}$ Department of Railway Transport, Faculty of Operation and Economics of Transport and Communications, University of Žilina, Žilina \\ 010 26, Slovak Republic \\ 2 Železnice Slovenskej republiky, 1. Mája 34, 01001 Žilina, Slovak Republic \\ 3 Železnice Slovenskej republiky, Klemensova 8, 813 61 Bratislava, Slovak Republic
}

\begin{abstract}
In view of a continuously growing freight turnover, the road transport has been increasingly developing not only in the Slovak Republic, but also in the European Union, as a whole. The European Union, by applying legal instruments, seeks to change the situation in favour of safer, more efficient and environmentally friendly modes of transport, such as railways and inland water transport. The railway scientists and experts from the Slovak Republic compare the transport and tariff conditions for the carriage of automobile tires by railway and road transport on the route Puchov - Hannover in a real environment. Based on the comparative analysis, they assess the time and economic indicators of complexity and efficiency in the transportation of a particular type of cargo on a particular route.
\end{abstract}

\section{Introduction}

The international transport of goods and the transportation contracts under which they are carried out are the most commonly used type of contract, in addition to the international agreements for the purchase and sale, and create a kind of bridge between the different transport organisations. International freight transport can be considered secondary neither from the legal nor from the commercial points of view.

One of the most important criteria is the cost of transportation, which can significantly affect the final price of goods on the market and, therefore, the consumer choice. In addition, this the criterion that must be taken into account by business partners.

The transportation of goods and cargoes in international traffic depends on a number of important criteria in the field of transport security (including legal, economic, and contractual and transport security). [1,2] All types of processing and handling can be carried out by a specific freight forwarding company, whose task is to provide the most suitable vehicles and to ensure the integrated transport Services. This is due to a high degree of inaccessibility of some railway infrastructure objects and their depreciation. In the current economic conditions within the EU, it is very difficult to forecast the development of freight railway transport in Slovakia. Due to certain instability in the Steel and automotive industries, significant decline in the productivity of railway transport may be observed as well. On the contrary, given the growing trend of globalization, there will most likely be further positive developments in intermodal transport. Apparently, intermodal transport is an important lever for the development of railways. To ensure further sustainable development, it is essential to create all necessary conditions, including a reliable railway infrastructure, flexible Services in accordance with customer requirements and an optimized terminal network. [3]

Road transport provides such Services, because of which "door-to-door" transportation is ensured almost anywhere in the world. Road transport is flexible, with minimal administrative delays associated with loading, and the driver throughout the transportation controls the cargo. Fast delivery of goods for short distances has no competition. Another advantage of road transport is the low cost of the Services it provides, which is beneficial even for carrying lightweight and special cargoes, accompanied by less damage during the transportation. [4]For longer transport distances, the delivery time is limited to the AETR (European Agreement on the Work of Crews in International Road Transport).

\section{Analysis of freight transport development in the EU}

The main transport problems in the European Union include the unbalanced development of various modes of transport, congestions of road infrastructure, as well as of the airspace, and the negative impact of transport on the environment. $[5,6]$

The efforts undertaken to limit the efficiency of road transport and its reorientation onto the railway transport have been developed by the EU in a number of regulations and national documents. First, the White Paper and the Lisbon Strategy are meant. [7]

\footnotetext{
* Corresponding author: lenka.cerna@,fpedas.uniza.sk
} 
It should be noted that not only in the Slovak Republic, but also in other EU countries, road freight transport has the largest representation. This is due to the fact that road transport is cheaper for the client, more attractive, more adaptable to the customers' specific requirements, and, because of the high competition, carriers are ready to significantly reduce the cost of transportation (provide discounts), which ultimately becomes unrealistically realistic. One of the most important criteria is the speed of delivery. From the point of view of the share of road freight transport in the EU the first place is occupied by Germany $(36 \%$ of the total volume of goods transported), then comes France (22\%), and the UK $(18 \%)$ in third place (according to the Statistical Office of the Slovak Republic). [8]

By railways, the speed of transportation is higher, especially when it goes to the block trains, and the cost of carriage is higher, too, since it includes other costs associated with the transportation itself, including the costs for weighing, handling, sealing or loading and unloading. For this reason, railway transport for the customer may be less attractive. Basing on the analysis of railway transport in the European Union, it can be concluded that the largest share of freight railway traffic is again in Germany (37\%), second in Austria (20\%), and third in the UK (11\%) (According to the data of the Statistical Office of the Slovak Republic).

\section{The initial parameters for the transportation of tires at the railway section Puchov - Hannover}

On the Puchov-Hannover railway route, automobile tires with the dimensions of $385 / 55 \mathrm{R} 22.5$ for trucks are delivered. The reason why the loading of a batch of tires is performed at the Puchov station is that a railway siding to the main network connects the manufacturing enterprise producing the tires. [9]

Railways in a special transport tires. Transport swap body belonging to the Deutsche Bahn AG (the so-called Container or transport unit) - "DB-Megabox", which was specially designed for the transportation of automobile parts. These swap bodies are also used in road transport using a special combination with a hydraulic lifter.

In railway traffic, wagons of "Sgkkms" type are used for the carriage of "DB-Megabox" transport units. Since "DB-Megabox" containers are special swap bodies, they are classified as special cargo consignments when transported by railway. On the other hand, trailers are used for the carriage by road. Railways deliver the cargo through the border crossing points of Lúky pod Makytou - Horní-Lideč, Děčín - Bad-Schandau, and by road through the border crossing points of Drietoma and Ústi nad Labem. [10]

Basic parameters for railway transportation:

- Type of transportation: transportation under special conditions.

- Goods type: tires 385/55R 22.5.

- Number of tires in one Container (swap body): 120 pes.

- Transport unit (TE): “DB-Megabox" swap bodies;
- Wagon type: "Sgkkms".

- Number of transport units: Two swap bodies on one Hat wagon;

- Auxiliary transport equipment: Two fixing rods.

- Cargo weight: 9600 kg.

- Loading station: Puchov.

- Unloading station: Hannover Linden.

- Border Crossing points: Slovakia - Lúky pod Makytou, Czech Republic - Horní Lideč, Děčín, Germany - Bad Schandau.

- Distance: $891 \mathrm{~km}$.

- Delivery time: 4 days.

\subsection{Railway delivery route plan}

Figure 1 shows the route plan of goods railway delivery on the railways of Slovakia, Czech Republic and Germany.

\section{Characteristics of DB-Megabox transport unit (TU)}

The "DB-Megabox" swap bodies are used for the transportation of tires on the Puchov-Hannover railway route, referred to as transport units (TU). The special transport unit of "DB-Mega- box" type was developed jointly by DB Cargo, DB Technical Centrum Minden and Continental AG. They represent a combination of large containers with open top. They are all-metal boxes on four legs, which are suitable for the transportation by using special road vehicles equipped with a lifting platform, as well as for the transportation on railway fiat wagons. The main characteristics are shown in Table 1.

Fig. 1. Railway delivery route plan

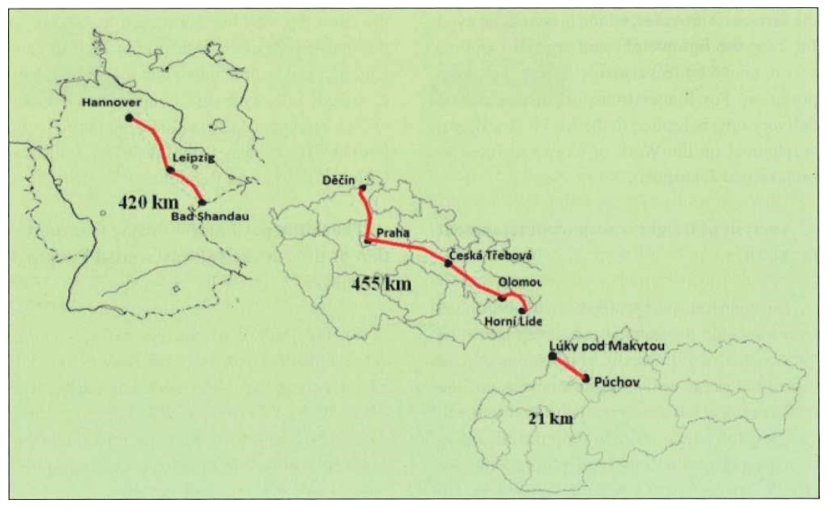

Table 1. Characteristics "DB-Megabox "transport.

\begin{tabular}{|c|c|}
\hline External dimensions $(\mathrm{m})$ & $7,82 \times 2,60 \times 3,29$ \\
\hline Internal dimensions $(\mathrm{m})$ & $7,67 \times 2,52 \times 3,03$ \\
\hline Loading capacity $\left(\mathrm{m}^{3}\right)$ & 58,5 \\
\hline Maximum load $(\mathrm{kg})$ & 11255
\end{tabular}




\begin{tabular}{|c|c|}
\hline Container tare weight $(\mathrm{kg})$ & 4745 \\
\hline Total weight $(\mathrm{kg})$ & 16000 \\
\hline
\end{tabular}

These open-top containers - swap bodies are transported by railway mainly on special railway fiat wagons, since their width exceeds the maximum permitted by Regulation 349/2009 Coll. in relation to the maximum dimensions and mass of vehicles. Figure 2 shows a "DB-Megabox" transport unit and its loading onto the "Sgkkms" fiat wagon by using a special loader.

In railway transport these open-top transport units do not correspond to the maximum permissible overall dimensions in height, therefore specially designed and modified "Sgkkms" fiat wagons are used for their transportation by rail. [11] The "Sgkkms" fiat wagon used to provide the carriage of tires in "DB-Megabox" container type swap bodies is a modified fiat wagon with the loading surface level lowered $33 \mathrm{~cm}$ below the standard ( $845 \mathrm{~mm}$ above the rail) used in the "classical" freight wagons, which corresponds to the permitted dimensions for the transport of "DB-Megabox" TUs. The basic data of the fiat wagon is shown in Table 2 . Two containers can be transported on one fiat wagon at the same time. For loading and unloading the Container onto/from the fiat wagon a special loading and unloading device with clamp-like cramps (the so-called ,spreadrom') is used.

Table 2. Characteristics of "Sgklans " flat wagon

\begin{tabular}{|c|c|}
\hline Wagon length with buffers $(\mathrm{mm})$ & 19130 \\
\hline Length of the loading surface $(\mathrm{mm})$ & 15890 \\
\hline Floor height above the rail $(\mathrm{mm})$ & 854 \\
\hline Maximum load weight $(\mathrm{kg})$ & 46000 \\
\hline Maximum permissible speed $(\mathrm{km} / \mathrm{h})$ & 120 \\
\hline
\end{tabular}

Two "DB-Megabox" TUs can be loaded onto one "Sgkkms" fiat wagon. Figure 3 shows special wagons with lowered floor along with the loaded "DBMegabox" transport unit. [12]

\subsection{Loading of tires for railway transportation}

The cargo inside the open-top container-type swap body should be evenly distributed, fixed sufficiently to avoid the displacement, sheltered and protected from damage by the appropriate material. Before being loaded, the "DB-Mega- box" transport units are cleaned and checked. [13] The consignor with the use of his own loading equipment provides the loading. It takes an average of 90 minutes to load one Container (distribution of tires by type, preparation of the ramp, loading of the cargo itself). Tires through the open top are lowered onto special tube-type rods (Figure 4). 8 truck tires with the dimensions of $982 \times 212 \mathrm{~mm}$ and with the weight of 40 $\mathrm{kg}$ of one tire are placed on one rod. Tires are located next to each other and, thus, are fixed from over- timing. Two fixing rods are fitted on a TU's body to prevent the load from overtiming when the front door is opened. After loading and securing the cargo, the top is closed, locked and sealed with three seals. Then the data on the seals are entered into the wagon sheet, which is attached to the consignment load.

Fig. 2. Transport unit (TU) "DB-Megabox" and its loading onto the fiat wagon "Sgkkms" by means of a special loader

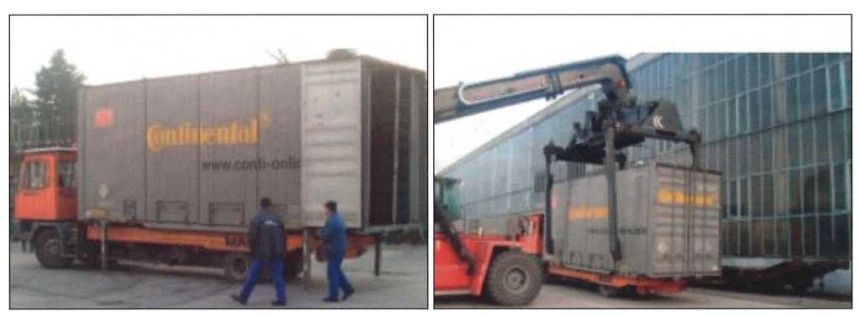

Fig. 3. A flat wagon of "Sgkkms" type loaded with two "DBMegabox" container-type transport units

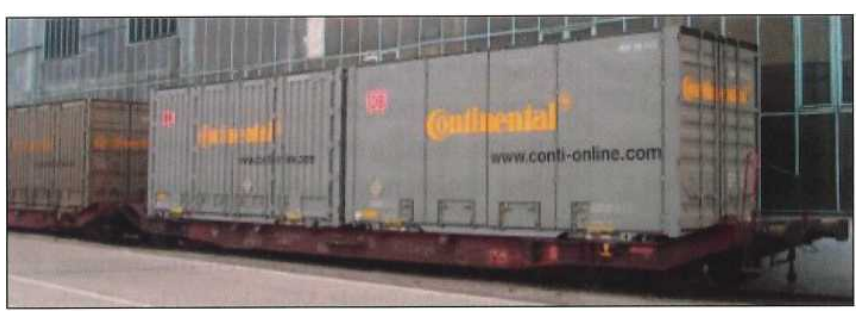

The railway carrier provides the delivery of goods to the industrial siding tracks. Unloading is provided by the consigner, which in this time is covered by a special procedure. In accordance with the UIC Loading Regulations, a cargo is considered to be a special cargo when its external dimensions, weight or nature cause special difficulties when it is processed by railway equipment and when transported by railway rolling stock of one of the participating railways and, therefore, can only be accepted for the transportation under special technical or operating conditions. Specific goods can be accepted for the transportation only under special conditions, which must be agreed in advance between the carrier and the railway undertaking (UIC Loading Regulations). [14]

\subsection{Technology of cargo handling on railway siding tracks (loading tires in a transport unit)}

Comparing the carriage conditions of tires by railway and road transport, the technology of their unloading and processing can be also analysed, i.e. the process of handing over a 'relay baton' from the road carrier to the railway carrier at the place where the tires were loaded into the railway containers before they were sent from the siding tracks. [15]

The analysis shows that 20 standard operations are required for loading and carriage by rail, and only seven - for road transport.

\subsection{Analysis of tariff conditions for the carriage of tires by rail on the route Puchov - Hannover}

In the context of studying of the cost of railway

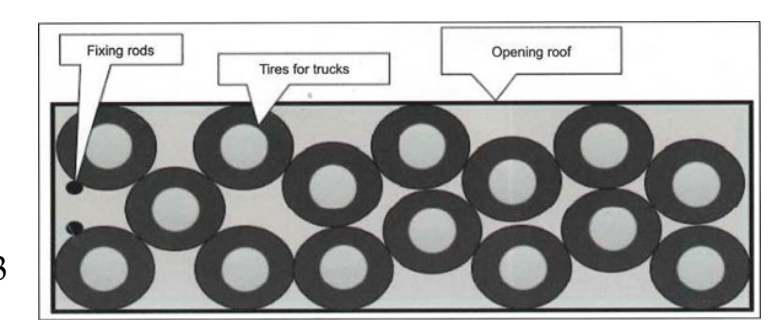


transport, ten carriers were considered who provide transport Services in Slovakia and provide the delivery by rail. The information provided by three of them is given in Table 3 . The tariffs for carriage of goods in the Puchov-Hannover traffic are presented in two versions: when transporting the same number of tires in one large Container and in two swap bodies. [16, 17]

Fig. 4. Stowing of tires in a Container

Table 3. Examples of tariff conditions for the carriage of tires by railway on the route Puchov - Hannover

\begin{tabular}{|c|c|c|}
\hline \multicolumn{3}{|c|}{ Information, received from selected railway carriers } \\
\hline & $\begin{array}{c}\text { Price for a carrier's } \\
\text { wagon in euros }\end{array}$ & $\begin{array}{c}\text { Price for a consignor's } \\
\text { wagon in euros }\end{array}$ \\
\hline Carrier 1 & 2138 & 1932 \\
\hline Carrier 2 & 2300 & 2070 \\
\hline Carrier 3 & 3902 & 3175,30 \\
\hline
\end{tabular}

\subsection{Basic parameters for transportation by road}

Transportation of tires by road differs from that by rail, mainly by the choice of the vehicle used to carry out this transportation. While in railway transport container-type swap bodies are used as transport units, in road freight traffic a special semitrailer with reinforced sideboards is used for the carriage of tires. This is because "DBMegabox" transport units do not meet the maximum width requirements for road transport. [18]

- Type of transport: international freight trans-port.

- Goods: tires 385/55 R 22,5.

- Number of tires in one TU: 240 pes.

- Transport unit: Fliegel semitrailer with rein- forced sideboards.

- Axillary equipment: slings.

- Freight weight: $9600 \mathrm{~kg}$.

- Loading station: Puchov.

- Unloading station: Hannover Linden.

- Border Crossing points: Slovakia - Drietoma, Czech Republic - Ústi nad Labem.

- Distance: $880 \mathrm{~km}$.

- Time of delivery: 2 days.

\subsubsection{Characteristics of transportation by road}

Figure 5 shows the route of cargo delivery by road passing through Slovakia, Czech Republic and Germany, together with the marked border Crossing points. Border crossings through which the road transport route passes are: in the territory of Slovakia - Drietoma, and in the Czech Republic - Ústí nad Labem. [10]

Fig. 5. Road delivery route plan

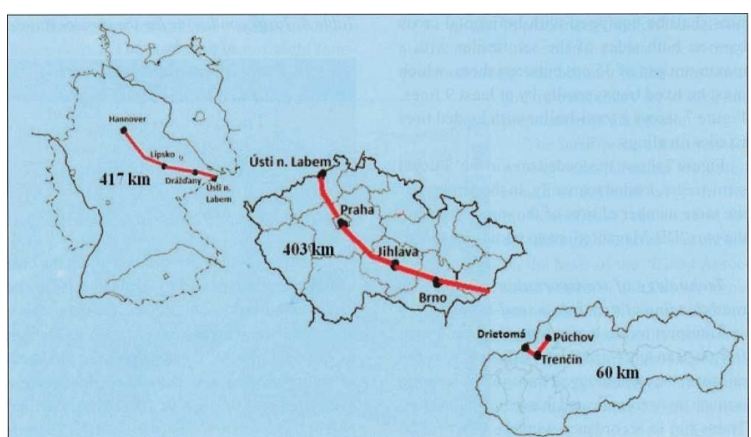

\subsubsection{Characteristics of an automobile semi-trailer}

When transporting tires by road, a special semitrailer was chosen for the transportation of tires with reinforced side boards, as shown in Figure 6.

Fig. 6. Semitrailer used f or road transport

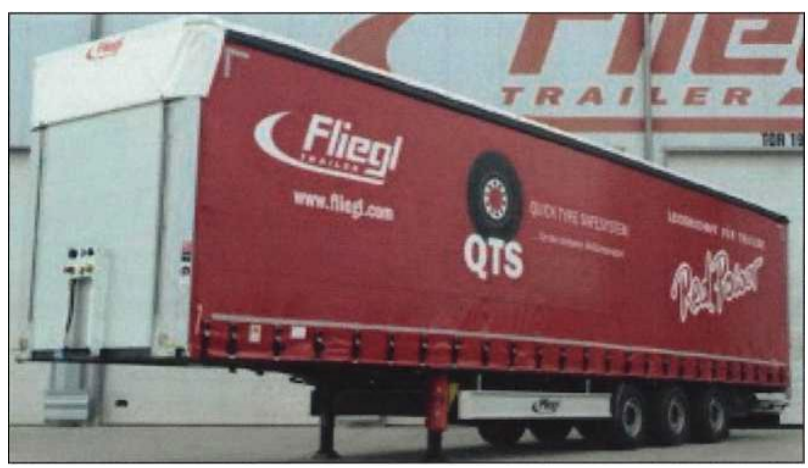

In the time of road transport, the carrier submits for transportation a vehicle authorized for transportation. The driver shall take part in the loading and unloading process of the vehicle, but does not performs either loading or unloading himself. The driver must check the external condition of the cargo, its quantity and packaging, as well as identify the damages, if there are any, to indicate them in the consignment note, and notify the consignor in time of improper loading and securing the cargo. The semitrailer used for the carriage of tires shall be equipped with horizontal crossbars on both sides of the semitrailer with a maximum gap of $35 \mathrm{~cm}$ between them, which must be fixed transversally by at least nine lines. Figure 7 shows a semi-trailer with loaded tires fixed with slings. [7, 9]

Figure 7 shows the loaded tires in the "Fliegl"semitrailer, loaded manually. In the semitrailer the same number of tires of the same type as in the two "DBMegabox" swap bodies is placed.

Technology of transportation of goods by road (loading of tires into a semi-trailer)

Transport technologies for railway and road freight transport are very different. On the railways, the technology of transport processing is much more complicated than in road transport. Trains run in accordance with the exact traffic timetable. [10]

The so-called, hierarchyl of traffic exists on the railways. In most cases, priority is given to passenger trains, and then preference is given to regular (route or block) freight trains, and, in the end, trains with irregular traffic follow. In road transport, the carrier is guided by the terms of transportation and is limited only by the ban on traffic during public holidays and on weekends or by the provisions of the European agreement concerning the work of crews of vehicles engaged in international road transport. $[3,5,9]$

Fig. 7. Example of stowed tires and their fastening with slings 


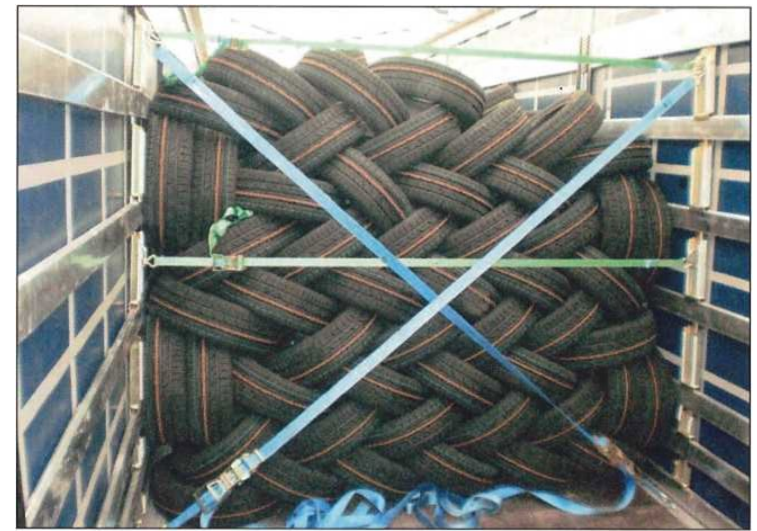

\section{Analysis of tariff conditions for the transportation of tires by road on the route Puchov - Hannover}

The cost of transportation of goods by road from Puchov to Hannover was analysed using the Internet resources of individual road carriers. The data of five road carriers were analysed. Table 4 shows the information of three out of five carriers.

Carriers provided information about the cost of transportation per $1 \mathrm{~km}$. Travel costs for the driver amounted to 56.11 euros for the mentioned countries, whereas travel expenses amount to 219.63 euros. Of these values, the total cost of transportation was calculated, including a calculated profit margin of $10 \%$. Thus, the final cost of transportation ranges from 1077.72 euros to 1222.92 euros for each load carried.

Table 4. Tariff conditions for the transportation of tires by road

\begin{tabular}{|c|c|c|}
\hline \multicolumn{2}{|c|}{ Information provided by selected automobile carriers } \\
\hline & $\begin{array}{c}\text { Price per } 1 \mathrm{~km} \text { in } \\
\text { euro/km }\end{array}$ & $\begin{array}{c}\text { Cost of } \\
\text { transportation in euros }\end{array}$ \\
\hline Carrier 1 & 0.80 & 1077.72 \\
\hline Carrier 2 & 0.87 & 1145.45 \\
\hline Carrier 3 & 0.95 & 1222.92 \\
\hline
\end{tabular}

Evaluation of selected conditions for the carriage of tires by railways and by road transport

Table 5. Compares tariffs for road and railway freight traffic on the mentioned route.

\begin{tabular}{|c|c|c|}
\hline \multicolumn{2}{|c|}{$\begin{array}{c}\text { Comparison of the cost of transportation of tires by } \\
\text { railways and by road transport }\end{array}$} \\
\hline & $\begin{array}{c}\text { Cost of } \\
\text { transportation by rail }\end{array}$ & $\begin{array}{c}\text { Cost of } \\
\text { transportation by road }\end{array}$ \\
\hline Carrier 1 & 1932 & 1077.72 \\
\hline Carrier 2 & 2070 & 1145.45 \\
\hline
\end{tabular}

\begin{tabular}{|l|l|l|}
\hline Carrier 3 & 3175.30 & 1222.92 \\
\hline
\end{tabular}

This table shows that the cost of freight transportation by road is about half of the cost of the transportation by railway. Therefore, for a Client, automobile transportation is more economically sound than transportation by railway.

The cost of transportation by road on the route Puchov - Hannover is 1077.72 euros and 1222.92 euros for a load shipment. In all cases, carriers calculated the cost of international transportation performed within the period of one day. Swap semi-trailers and wagons belong to the customer. The cost of railway freight transportation on the same route amounts from 1,932 euros to 3,175.30 euros for one fiat wagon sent, i.e. two removable Container bodies belonging to the customer. If the fiat wagon or transport unit do not belong to the consignor, the cost of transportation would be 2138 3902 euros for a load shipment. In most cases, carriers could provide tariffs for the transportation within a period of 3 days. The indicated cost of delivery is calculated based on the tariff. If it were a normal delivery, the delivery cost could be reduced by $10-15 \%$.

The conditions for the transportation by railway and by road are very different. Table 6 presents a brief comparison of transport and tariff conditions. $[2,11]$

The responsibility of the carrier for the transportation by road is $8.33 \mathrm{XDR} / \mathrm{kg}$ gross weight of a damaged or lost consignment, and in railway transport - $17 \mathrm{XDR} / \mathrm{kg}$, which demonstrates the carrier's greater responsibility for the damage or loss of goods in the transportation by rail. In time of delay, the carrier is liable: when transporting by road - up to the price of transportation, when carrying by rail - up to four times of the cost of transportation. The delivery time in both cases is agreed in the contract between the consignor and the carrier. If the delivery time is not agreed by the contract, the time of delivery by rail shall not exceed the specified time of delivery and handling of the goods. In road transportation, the delivery time cannot be more than the actual time of transportation taking into account the circumstances and time necessary for loading and preparation of the vehicle.

The tariff/price conditions for railway transportation are deter- mined in different ways. In this particular time, the method for determining the price was chosen on the basis of the "Client Agreement", because the fare for transportation on this route does not include the cost for the transportation of an intermodal transport unit (swap body). Selected railway and road carriers were chosen. In road transport, the cost of transportation is calculated using individual calculations of carriers. On the chosen route and with the selected transport criteria, the most economical is road transport.

Fig. 8. Comparison of transport and tariff conditions 


\begin{tabular}{|c|c|c|}
\hline \multicolumn{3}{|c|}{ TRANSPORT CONDITIONS } \\
\hline & Railway transport & Road transport \\
\hline Responsibility in accordance with & COTIF Convention, JPP CIM & CMR Convention \\
\hline Responsibility for providing data & Consignor & Consignor \\
\hline $\begin{array}{l}\text { Liability of carrier in case of loss } \\
\text { or damage }\end{array}$ & $17 \mathrm{XDR} / \mathrm{kg}$ & $8,33 \mathrm{XDR} / \mathrm{kg}$ \\
\hline Liability of carrier in case delay & $\begin{array}{l}4 \text { times of the cost of } \\
\text { transportation }\end{array}$ & $\begin{array}{l}\text { Up to the cost of } \\
\text { transportation }\end{array}$ \\
\hline $\begin{array}{l}\text { Number of copies of consignment } \\
\text { notes }\end{array}$ & 5 & 4 \\
\hline $\begin{array}{l}\text { Responsibility for measuring the } \\
\text { weight of load }\end{array}$ & Consignor & Consignor \\
\hline Departure control & Carrier & Carrier \\
\hline Estimated delivery time & $\begin{array}{l}\text { According to the contract } \\
\text { but not longer than the time } \\
\text { required for handling and } \\
\text { delivering }\end{array}$ & $\begin{array}{l}\text { According to the contract } \\
\text { but not longer than the actual } \\
\text { time of delivery }\end{array}$ \\
\hline Claims & $\begin{array}{l}\text { In accordance with the } \\
\text { contract }\end{array}$ & $\begin{array}{c}\text { Within } 7 \text { days after the goods } \\
\text { have been received - for an } \\
\text { obvious damage, } 7 \text { days after } \\
\text { the moment a hidden damage } \\
\text { has been detected }\end{array}$ \\
\hline Statute of limitations & 1 year & $\begin{array}{c}1 \text { year, intentional damage - } \\
3 \text { years }\end{array}$ \\
\hline & TARIFF CONDITIONS & \\
\hline Method of pricing & Client agreement & Individual calculation \\
\hline Unit of calculation & Price / 1 wagon & Price $/ 1 \mathrm{~km}$ \\
\hline
\end{tabular}

\section{Conclusion}

The conditions for the transportation in international and domestic freight traffic are analysed taking into account the time and cost- effectiveness. For the customer ordering the transportation, the economic component consists of the total cost spent for transportation. The time of delivery is the time required for transportation.

The reasons why the road freight transport in the European Union has the largest share in the transport market is not only the price, but also the delivery time. When comparing transportation by road and rail, the delivery time for most customers is determinative. In this time, road freight transportation was twice as fast as compared to the railways. The duration of transportation is determined taking into account the time of delivery and handling of the goods, which are only indicative. If it were certified regular transports, then the transportation time would be 24 hours. Comparing the tariff and time conditions of these transportations, it can be mentioned that railway transportation in this time is not competitive with respect to the road transport.

The purpose of this article was to compare the transportation and tariff conditions in railway and road transport, taking into account the selected criteria on the route Puchov - Hannover, basing on the analysis of the relevant provisions of the Convention on the Contract for the International Carriage of Goods - CMR and the Uniform Rules of COTIF Convention, regulating the conditions for the transportation of goods by rail and by road. The results of the analysis can be used in practice to select a more advantageous option. Both railway and automobile carriers provided data on delivery tariffs and conditions.

This research was financially supported by the project VEGA No. 1/0019/17 Evaluation of regional rail transport in the context of the region's economic potential focusing on the efficient use of public resources and social costs of transport.
1. A. Dolinayová E. Nedeliaková. Proceedings of the 16th International Symposium Eurnex - Žel, 101 $108,(2008)$

2. G. Fedorko, V. Molnár, M. Kopas,, Tem journal technology education management informatics, 7, 3 (2008) DOI: 10.18421/TEM73-02

3. V. Lupták, J. Gašparík, M. Chovancová, MATEC Web of Conferences.134, 00033, (2017)

4. A. Dolinayová, J. Čamaj, J. Daniš, J. Globalization and its socio-economic consequences, 16 th International scientific conference proceedings, 383-390 (2016)

5. M. Zoldy, A. Torok. Period. Polytech. Transp. Eng., 43, 4, 172-176 (2015),

6. L. Černá, V. Klapita, J. Mašek, J. Technická základňa intermodálnej prepravy. 1st edition, (2015)

7. J. Ližbetin, O. Stopka, F. Nemec. Proceedings of the $20^{\text {th }}$ international scientific conference Transport Means 2016. 151 - 155. (2016)

8. M. Poliak. Transport and communications, 1 (190201. (2010).

9. J. Královenský, J. Gnap, M. Poliak, V. Konečný. Ekonomika cestnej a mestskej dopravy. 1, University of Žilina, ISBN 978-80-8070-831-3 (2008)

10. Transport development strategy for 2020 [on-line], (cited 12.02.2017)

11. G. Fedorko, V. Molnár, J. Strohmandl et al. Transport Means 2015 - Proceedings of the International Conference. 466-+ (2015)

12. T. Skrúcaný, J. Ponický, M. Kendra, J. Gnap Proceedings of the $3^{\text {rd }}$ International Conference on Traffic and Transport Engineering ICTTE 2016, 744-749. (2016).

13. M. Chovancová, V. Klapita. Open Engineering. 7.1, 50-54 (2017) DOI: 10.1515/eng-2017-0009

14. J. Majerčák, M. Plíhal, P. Majerčák. Modelovanie prepravy vybranej komodity $\mathrm{v}$ medzinárodnej preprave tovaru, 1st edition. (2016)

15. B. Buková, E. Brumerčíková, P. Kondek. Open Engineering. 7, 1. 14-18. (2017) DOI: 10.1515/eng2017-0003

16. Siroky, J. LOGI proceeding, MATEC, 134 (2017)

17. M. Poliak. EKONOMICKY CASOPIS. 61, 2. 206220. (2013)

18. L. Bartuska, O. Stopka, M. Chovancova, J. Lizbetin. Transport Means - Proceedings of the $20^{\text {th }}$ International Conference. 107-111 (2016)

19. A. Plakhin, R. Kampf, E. Ogorodnikova, A. Kokovikhin. MATEC Web of Conferences. 134, 00047 (2017) DOI: $10.1051 /$ matecconf/201713400047

\section{References}

